\title{
The Search for New Agonists to P2X7R
} for Clinical Use: Tuberculosis as a Possible Target

\author{
Rômulo J. Soares-Bezerra ${ }^{a}$ Rosa T. Pinho ${ }^{b}$ Rodrigo da C. Bisaggio ${ }^{c}$ \\ Thereza Christina Benévolo-de-Andrade ${ }^{b}$ Luiz A. Alves $^{a}$
}

aLaboratory of Cellular Communication, 'baboratory of Clinical Immunology, Oswaldo Cruz InstituteFIOCRUZ, 'Federal Institute of Education, Technology and Science of Rio de Janeiro-IFRJ, Rio de Janeiro, Brazil

\section{Key Words}

Agonists • P2X7R • Purinergic Receptors • Multidrug Resistance • Tuberculosis

\begin{abstract}
Treatment for tuberculosis is effective with the use of proper antibiotics, but the number of drug-resistant cases is increasing. Drug resistance occurred in 650,000 cases of the 20 million patients in treatment worldwide in 2011, which demonstrates the necessity of finding new therapeutic approaches. In this context, the search for new medicines and immunomodulators could help reduce the prevalence and incidence of multi-drug-resistant tuberculosis cases. Thus several preclinical studies demonstrate the involvement of the P2X7 receptor (P2X7R) in the control of Mycobacterium tuberculosis (MTB) infection. Adenosine triphosphate (ATP), a natural agonist for P2X7R, promotes MTB death and the induction of apoptosis in monocytes and macrophages infected with MTB via activation of P2X7R by extracellular ATP. In addition, P2X7R activation in the presence of ATP increases the expression of major histocompatibility complex (MHC) class II by macrophages infected with Mycobacterium bovis (BCG) or MTB, which contributes to the generation of the antimicrobial immune response via $T$ cells. Nevertheless, one idea that seems overlooked by the "purinergic community" is the use of the high-conductance channel associated with P2X7R to increase the passage of hydrophilic drugs to the cytoplasm of cells that express the P2X7 pore, a potential method for a drug delivery system. In this work, we propose the use of P2X7 agonists in conjunction with low molecular weight anti-tuberculosis medicines for the treatment of multi-drug-resistant tuberculosis.
\end{abstract}




\section{Cellular Physiology Cell Physiol Biochem 2015;37:409-418

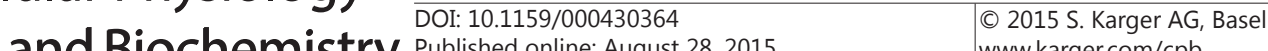 \\ \begin{tabular}{l|l|l|l|l} 
and Biochemistry Published online: August 28, 2015 & www.karger.com/cpb \\
\hline
\end{tabular} \\ Soares-Bezerra et al.: Agonists to P2X7R for Clinical Use in Tuberculosis}

\section{Introduction}

Tuberculosis (TB) is a chronic infectious airborne disease. Robert Koch identified its etiologic agent, Mycobacterium tuberculosis (MTB), in 1882 [1]. This disease primarily affects the lungs, which is the first organ to meet and receive the infecting bacilli. Therefore, pulmonary TB is the predominant form of this disease (approximately $70 \%$ of the cases). Furthermore, the bacilli may spread and infect other organs, such as the lymph system, bones and meninges, causing extra clinical pulmonary TB manifestations [2].

The Koch bacilli enter the lung parenchyma, infect macrophages and dendritic cells, which phagocytize MTB, and migrate through the lymphatic system to the regional lymph nodes [3]. Phagocytic cells remain in the lung parenchyma and initiate an inflammatory response, which attracts more leukocytes to the region. In this case, the accumulation of inflammatory cells around the bacilli leads to the development of a granuloma, a process that is coordinated by $\mathrm{T}$ cells [2]. Once the passage of the bacilli through the airway has begun, the MTB can spread and settle in any organ, either during the initial infection, when the adaptive immunity is not yet fully established, or during a late phase of the infection, which is related to a failure of the host's capacity to maintain the bacilli within the granuloma [3].

TB is most prevalent in low human development index countries or emergent economies [4]. Currently, TB is one of the top three causes of death in women aged 15-44 years in Brazil [5]. Recently, the number of TB cases has increased worldwide due to the emergence of multi-drug-resistant strains, the increase in cases of patients co-infected with both TB and HIV and the difficulties related to treatment. In 2011, 8.7 million people developed this disease, including 1.1 million cases of people co-infected with HIV, and approximately 1.4 million deaths from TB were registered [4].

Another concern involving TB is the increasing number of multi-drug-resistant TB (MDR-TB) strains, with an estimated prevalence of 650,000 cases in 2011 and approximately 150,000 deaths in 2008. MDR-TB is defined as resistance to isoniazid and rifampicin with or without resistance to other first-line drugs (FLDs) [5]. XDR (extremely drug-resistant) is defined as the resistance to at least isoniazid and rifampicin, or any fluoroquinolone, and one of the three second-line drugs (e.g., amikacin, capreomycin and kanamycin) [6]. The number of patients treated for MDR-TB rose to 46,000 in 2011 [1, 4]. This demonstrates the necessity of finding new therapeutic approaches. In this context, the search for new medicines and immunomodulators could help reduce the prevalence and incidence of multidrug-resistant tuberculosis cases [7].

\section{The P2X7R}

P2XR are receptors that have as physiological ligand ATP. They are ionotropic receptors, forming a non-selective cation channel when activated by agonists, which allows the passage of $\mathrm{Na}^{+}, \mathrm{Ca}^{2+}$ and $\mathrm{K}^{+}$ions across the cell membrane. The activation of these receptors results in a rapid increase in the intracellular calcium concentration, an important cellular messenger, as well as the depolarization of cells in a milliseconds range $[8,9]$. These receptors consist of only three protein subunits, each one consists of two transmembrane domains (TM1 and TM2), which are separated by an extracellular loop that contains ten cysteine residues that form disulfide bonds, and an intracellular amino residue (C) and a carboxy (C) terminal. $[9,10]$. Since 1994, seven subtypes of P2XR have been found in mammalian and cloned, which were named P2X1-7 and it is known that these receptors are widely expressed in different species of vertebrates [11]. The P2X1 subunits, 2, 3, 4 and 6 can interact to form homotrimeric or heterotrimeric channels. P2X5 is little active in the homotrimeric form, but appears to be functional in heterotrimeric forms: P2X1 / P2X5, P2X2 / P2X5 and P2X4 / P2X5 [12].

Likewise, P2X7R is the only one that works as a homotrimer and presents some outstanding characteristics. The first is the need for high concentrations of ATP to be 


\section{Cellular Physiology Cell Physiol Biochem 2015;37:409-418

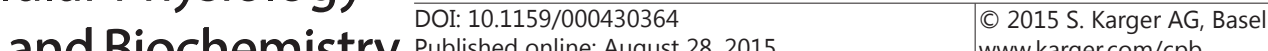 \begin{tabular}{l|l} 
and Biochemistry Published online: August 28,2015 & www.karger.com/cpb
\end{tabular}

activated; the P2X7R has an $\mathrm{EC}_{50} \geq 100 \mu \mathrm{M}$ to be activated, while other subtypes (P2X1-6) are activated in the range of $0.07-10 \mu \mathrm{M}$ ATP [13]. Another feature is the ability to form a pore membrane when activated by high ATP concentrations $(\geq 100 \mu \mathrm{M})$ or by prolonged exposure to this agonist. This allows the bidirectional transport of ions through the membrane pore, as well as, the passage of molecules with molecular weight up to $900 \mathrm{Da}$, except lymphocytes whose molecular weight limit is between 200-300 Da. This pore seems to be related to the cytotoxicity associated with P2X7R, and their formation depends on the intracellular C-terminal domain [8].

P2X receptors are expressed in different cell types, such as neurons, glial cells, epithelial cells, lung cells, muscle cells, endothelial cells and immune cells, including macrophages, monocytes and lymphocytes among other cells $[9,12]$. Because of this wide expression in many biological systems and the promoted effects reported, the P2XR has been increasingly studied as a potential therapeutic target for several diseases, including chronic inflammatory diseases and pain. In fact, it is already described in the literature that the use of certain selective antagonists for some of these receptors subtypes, such as P2X3R and P2X7R, e.g., in animal models, have shown promising anti-nociceptive and anti-inflammatory effects [11].

There are some effects related to P2X7R activation, including the regulation of the expression and release of some cytokines, inflammatory mediators and inflammatory metabolites, including interleukin (IL)-1 $\beta$ [14], IL-1 $\alpha$ [15], IL-2 [16], IL-4, IL-6, IL-13, IL-18 [14, 17-19], tumor necrosis factor (TNF)- $\alpha$ [14], nitric oxide (NO) [20] and superoxide anions $[21,22]$. The correlation between P2X7R and the process of IL-1 $\beta$ release is described in the literature, which shows an early involvement of caspase- 1 activation through mechanisms dependent on the inflammasome complex [14]. We can also highlight the formation of multinucleated giant cells [23, 24], the induction of MTB death [25], cytoskeletal reorganization [26] and caspase activation [27].

\section{P2X7R and Tuberculosis}

Recently, several studies have indicated an important role of P2X7R in MTB infection (Table 1) $[25,28]$. Macrophages obtained from humans with $1513 \mathrm{~A} \rightarrow \mathrm{C}$ polymorphism in the P2X7R gene and infected with MTB do not suffer apoptosis and fail to induce mycobacterial death when treated with ATP [29]. Similar results were observed with human macrophages infected with MTB [28, 30]. However, one study conducted in 2006 by Placido et al. [31] showed that extracellular ATP induces apoptosis in monocytes/macrophages infected with MTB via the P2X7R and reduces bacilli viability. The immunomodulatory effect of extracellular ATP was also described through P2X7R activation, which increases major histocompatibility complex (MHC) class II expression in macrophages infected with Mycobacterium bovis (BCG) or MTB and contributes to the generation of the antimicrobial $\mathrm{T}$ cell response [32]. In addition, a recent work published by Amaral et al. [33] proposed the blocking of P2X7R during hypervirulent and aggressive infections. Since this receptor acts on cellular pathways, which leads to a secretion of pro-inflammatory cytokines, such as the IL-1 $\beta$. The overstimulation of the immune response promoted by the hypervirulent infection, added to the activation of the P2X7R, could lead to an intense cellular necrosis generating the lung necrosis [33]. It is important to point out that hypervirulent infections are different from MDR and XDR infections. In keeping with the physiological role of the P2X7R in tuberculosis, several case-control studies have shown susceptibility to tuberculosis in single P2X7R polymorphisms of the P2X7R [34]. The most relevant association has been observed with 153A/C mutation; a recent meta-analysis has concluded that it is a risk factor for pulmonary and extra-pulmonary tuberculosis in Asians [35]. Li et al. pointed to the inhibition of the biosynthesis and activity of mycobacterial siderophores as a way to impair the proliferation, virulence and latency of the bacillus [36]. Abate et al. showed that patients with gene mutations for Rifampicin and/or isoniazid resistance showed no correlation with 


\begin{tabular}{|c|c|c|}
\hline Cellular Physiology & $\begin{array}{l}\text { Cell Physiol Biochem 2015;37:409-418 } \\
\text { DOI-100115/000430364 }\end{array}$ & \\
\hline and Biochemistry & $\begin{array}{l}\text { DOI: 10.1159/000430364 } \\
\text { Published online: August 28, } 2015\end{array}$ & $\begin{array}{l}\text { (0 } 2015 \text { S. Karger AG, Basel } \\
\text { www.karger.com/cpb }\end{array}$ \\
\hline
\end{tabular}

Table 1 The role of the P2X7R in Mycobacterium tuberculosis infection

\begin{tabular}{|c|c|c|}
\hline P2X7R Context & Experimental Model & Reference \\
\hline $\begin{array}{l}\text { ATP treatment of infected macrophages induces } \\
\text { Mycobacterium bovis (BCG) death through P2X7 activation }\end{array}$ & $\begin{array}{l}\text { Human peripheral blood mononuclear cell (PBMC)-derived } \\
\text { macrophages }\end{array}$ & [67] \\
\hline $\begin{array}{l}\text { ATP treatment of infected macrophages induces BCG } \\
\text { death through P2X7 activation }\end{array}$ & Cell lines and murine macrophages & [68] \\
\hline $\begin{array}{l}\text { P2X7 gene polymorphism }(1513 \mathrm{~A} \rightarrow \mathrm{C}) \text { impairs BCG killing } \\
\text { by ATP treatment of infected macrophages }\end{array}$ & $\begin{array}{l}\text { Primary culture of macrophages from individuals } \\
\text { homozygous for the } 1513 \mathrm{~A} \rightarrow \mathrm{C} \text { allele }\end{array}$ & [25] \\
\hline $\begin{array}{l}\text { Different P2X7 gene polymorphisms diminish or abolish } \\
\text { BCG killing by ATP treatment of infected macrophages }\end{array}$ & $\begin{array}{l}\text { Primary culture of macrophages from single and compound } \\
\text { heterozygous individuals with different P2X7 gene } \\
\text { polymorphisms }\end{array}$ & [28] \\
\hline $\begin{array}{l}\text { ATP treatment of infected macrophages induces } \\
\text { Mycobacterium tuberculosis (MTB) death through P2X7 } \\
\text { activation }\end{array}$ & Primary culture (human macrophages) & {$[31]$} \\
\hline $\begin{array}{l}\text { P2X7 gene polymorphism }(1513 \mathrm{~A} \rightarrow \mathrm{C}) \text { is associated with } \\
\text { increased vulnerability to extrapulmonary tuberculosis } \\
\text { (TB) }\end{array}$ & Human monocyte-derived macrophages & [29] \\
\hline $\begin{array}{l}\text { Involvement of the P2X7R in IL- } 1 \beta \text { release induced by } \\
\text { MTB }\end{array}$ & Human PBMCs & [69] \\
\hline Increase in MHC Class II expression & Murine macrophages & {$[32]$} \\
\hline Absence of P2X7R in mice increases the MTB infection & $\mathrm{P} 2 \mathrm{X} 7 \mathrm{R} \%$ mice & [66] \\
\hline
\end{tabular}

resistance to second line medicines. To second line medicines, although the treatment of these patients with high doses of Rifampicin or Isoniazid was shown to be non-effective [37].

\section{Clinical use of ATP}

The clinical use of ATP in the treatment of many diseases can be controversial, since the wide distribution of $\mathrm{P} 1$ and $\mathrm{P} 2$ receptors in the human body, and its degradation by ectonucleotidases, which could result in terrible side effects. Thereto, the first article that showed the use of ATP in humans was published in the 40's, in order to treat rheumatoid arthritis [38], in which the authors claimed an improvement or completely recovery, in a long or short period of time after the treatments, in 66 per cent of the 144 patients studied.

In 1996, Haskell and co-workers returned to evaluate the clinical use of ATP. They described the pharmacodynamics of ATP in humans, based on a phase I study, in which they measured the toxicity, maximum safety tolerated dose (MTD), and pharmacokinetics of intravenous ATP [39]. In this work, the patients received 96-hour infusions of ATP monthly in doses ranging from 50 to 100 micrograms $/ \mathrm{kg} /$ minute. They concluded that lenghty infusions of ATP are possible, including an acceptable toxicity, and that 50 micrograms $/ \mathrm{kg} /$ minute is both the MTD and the most appropriate dose rate for a Phase II study within a 96 hour scheme [39]. Since this study, many others have been published, studying the effects of ATP infusions in cancer, cachexia and as it been an energy source [39-44]. The majority of these works were cited in different therapeutic protocols as illustrated in Table 2. In addition, the most common side effects was a chest discomfort and the necessity to take a deep breath. In general, these side effects were managed by adjusting the infusion rate and its dosage [40, 45]. It is important to point out that patients with previous cardiopulmonary conditions had higher toxicity.

The final plasmatic concentration of ATP is complicated to determinate due to its degradation by ectonucleotidases present in the plasma, or expressed on the cell membrane of leukocytes or on endothelial cells. In addition, the erythrocytes acts as an ATP buffer as shown by Haskell et al. [39] and Agteresch et al. [43]. Actually, there are no data in relation to ATP concentration in the plasma or in the interstitial space in human beings. Howsoever, KARGER 


\section{Cellular Physiology Cell Physiol Biochem 2015;37:409-418

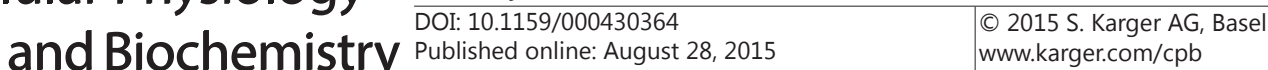

Table 2. Clinical Use of ATP

\begin{tabular}{|c|c|c|c|c|c|c|}
\hline $\begin{array}{l}\text { Number } \\
\text { of } \\
\text { Patients }\end{array}$ & $\begin{array}{l}\text { Route of } \\
\text { Administration }\end{array}$ & $\begin{array}{l}\text { Time of } \\
\text { Therapy }\end{array}$ & Used Dose & Side Effects & Results & $\overline{\text { Refe }}$ \\
\hline 8 & Oral & $\begin{array}{l}\text { One oral } \\
\text { dose }\end{array}$ & $5000 \mathrm{mg}$ & $\begin{array}{l}\text { No adverse } \\
\text { effects were observed } \\
\text { during the study }\end{array}$ & $\begin{array}{l}\text { ATP concentrations in blood } \\
\text { did not increase after ATP } \\
\text { supplementation via enteric- } \\
\text { coated pellets or } \\
\text { naso-duodenal tube }\end{array}$ & [49] \\
\hline 24 & Oral & $\begin{array}{l}\text { One oral } \\
\text { dose per } \\
\text { day during } \\
2 \text { weeks }\end{array}$ & $400 \mathrm{mg}$ & $\begin{array}{l}\text { No adverse } \\
\text { events reported in this } \\
\text { study. }\end{array}$ & $\begin{array}{l}\text { Enhanced muscular } \\
\text { adaptations following 12- } \\
\text { weeks } \\
\text { of resistance training, and } \\
\text { prevent decrements in } \\
\text { performance following } \\
\text { overreaching. }\end{array}$ & [70] \\
\hline 119 & Oral & $\begin{array}{l}\text { Three oral } \\
\text { doses per } \\
\text { day during } \\
4 \text { weeks }\end{array}$ & $120 \mathrm{mg}$ & Not evaluated & $\begin{array}{l}\text { supplementation of ATP after } \\
\text { surgery could improve TKA's } \\
\text { results }\end{array}$ & [50] \\
\hline 14 & $\begin{array}{l}\text { Parenteral } \\
\text { route }\end{array}$ & $\begin{array}{l}\text { 96-hour } \\
\text { infusions of } \\
\text { ATP once } \\
\text { monthly }\end{array}$ & $\begin{array}{l}\text { Doses ranging from } 50 \text { to } \\
100 \\
\text { micrograms } / \mathrm{kg} / \text { minute }\end{array}$ & $\begin{array}{l}\text { ATP was generally well } \\
\text { tolerated and no significant } \\
\text { hematologic toxicity was } \\
\text { noted. The dose-limiting } \\
\text { toxicity was a } \\
\text { cardiopulmonary reaction } \\
\text { characterized by chest } \\
\text { tightness and dyspnea that } \\
\text { resolved within seconds of } \\
\text { discontinuing ATP }\end{array}$ & $\begin{array}{l}\text { The authors conclude that the } \\
\text { maximum tolerate dose, and } \\
\text { also the most appropriate } \\
\text { dose rate is } 50 \\
\text { micrograms } / \mathrm{kg} / \text { minute }\end{array}$ & [39] \\
\hline 144 & ND & ND & ND & ND & $\begin{array}{l}\text { the authors observed an } \\
\text { improvement or recovered } \\
\text { completely, in a long or short } \\
\text { period of time, after the } \\
\text { treatments in } 66 \text { per cent } \\
\text { from the } 144 \text { patients studied }\end{array}$ & [38] \\
\hline 24 & $\begin{array}{l}\text { Parenteral } \\
\text { route }\end{array}$ & $\begin{array}{l}8 \text { infusions } \\
\text { weekly } \\
\text { during } 8 \\
\text { weeks of } \\
\text { treatment }\end{array}$ & $\begin{array}{l}25-50 \\
\text { micrograms } / \mathrm{kg} / \text { minute }\end{array}$ & $\begin{array}{l}\text { ATP administration at } \\
\text { home is safe. First, the } \\
\text { majority of infusions (63\%) } \\
\text { are } \\
\text { without side effects, that } \\
\text { side } \\
\text { effects that do appear are } \\
\text { mild and transient, } \\
\text { resolving within } \\
\text { minutes after lowering the } \\
\text { ATP infusion rate }\end{array}$ & $\begin{array}{l}\text { The authors, based on their } \\
\text { findings and in other previous } \\
\text { studies, they conclude that } \\
\text { ATP administration at home is } \\
\text { safe }\end{array}$ & [71] \\
\hline
\end{tabular}

in mice, several groups have found ATP in a concentration ranging a hundred micromolar in inflammation and tumoral sites $[46,47]$. Recently, a study using the technique of intravascular microdialysis demonstrated interesting results. In this study, Mortensen and cols show the venous and arterial ATP concentration in sixteen healthy young men. The arterial and venous concentrations of ATP were [109 \pm 34 and $147 \pm 45 \mathrm{nM} / \mathrm{L}]$ in rest. In addition, 7 minutes of ATP infusion $(0.4,0.8$ and $1.7 \mathrm{umol} / \mathrm{min})$ did not alter the concentration in the venous system. The T1/2 (half-life) found in this study was $<1$ s [48].

Presently, the oral administration of ATP as a dietary supplement, or medicine, has been applied in several countries [49]. This has generated several concerns about the efficacy and the safe use of ATP in humans; in this context, a recent randomized double-blind study has shown that oral ATP improved the recovery of patients submitted to Total Knee Arthrosplasty [50]. Some tuberculosis patients have a clinical profile similar to a terminal cancer patient $[51,52]$ when infected with untreatable MDR or XDR strains. Thus, in this condition, a clinical trial based on the use of ATP or a selective agonist for P2X7R could be approved, firstly, if they works well in animal models. Unfortunately, BzATP (the most selective agonist for P2X7R) has not been tested in humans to date. There are several studies, describing the action of this molecule in vivo using murine models [53-57].

A recent work published by Xu et al. [58] demonstrates that there are splice variants of the P2X7R with a difference in ATP responses, depending on which cell type expressing these responses. Then, it might be possible to synthesize agonists to act on the P2X7R expressed by macrophages, in this way, decreasing the possibility of serious side effects [58]. Although the research for new selective agonist molecules for P2X7R is scarce [59]. In this context, the 


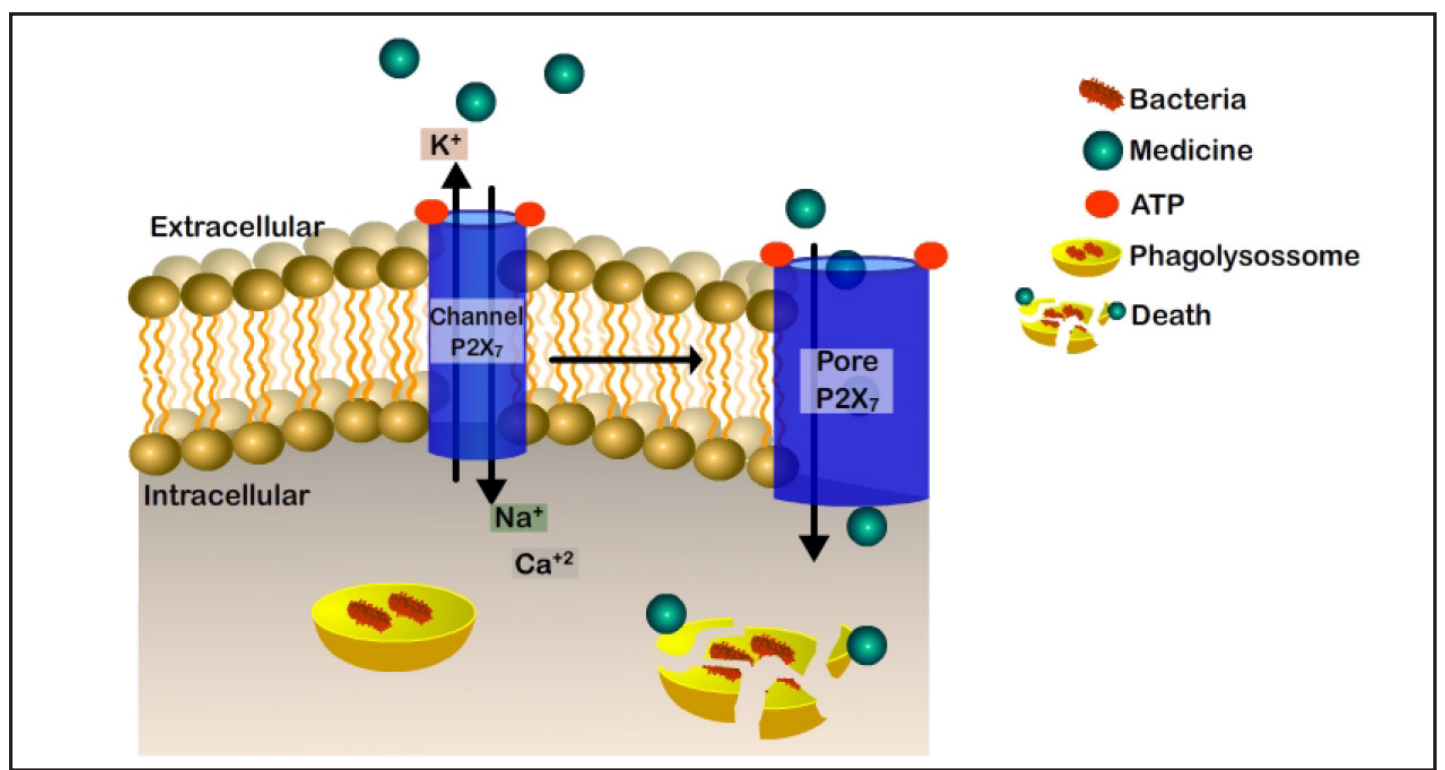

Fig. 1. The P2X7R property to open a membrane pore could be used to increase the delivery of hydrophilic or amphipathic antibiotics to the cellular cytoplasm, such as isoniazid (MW: 137.14 Da), rifampicin (MW: 822.94 Da), ethambutol (MW: 277.2 Da) and ethionamide (MW: 166.2 Da).

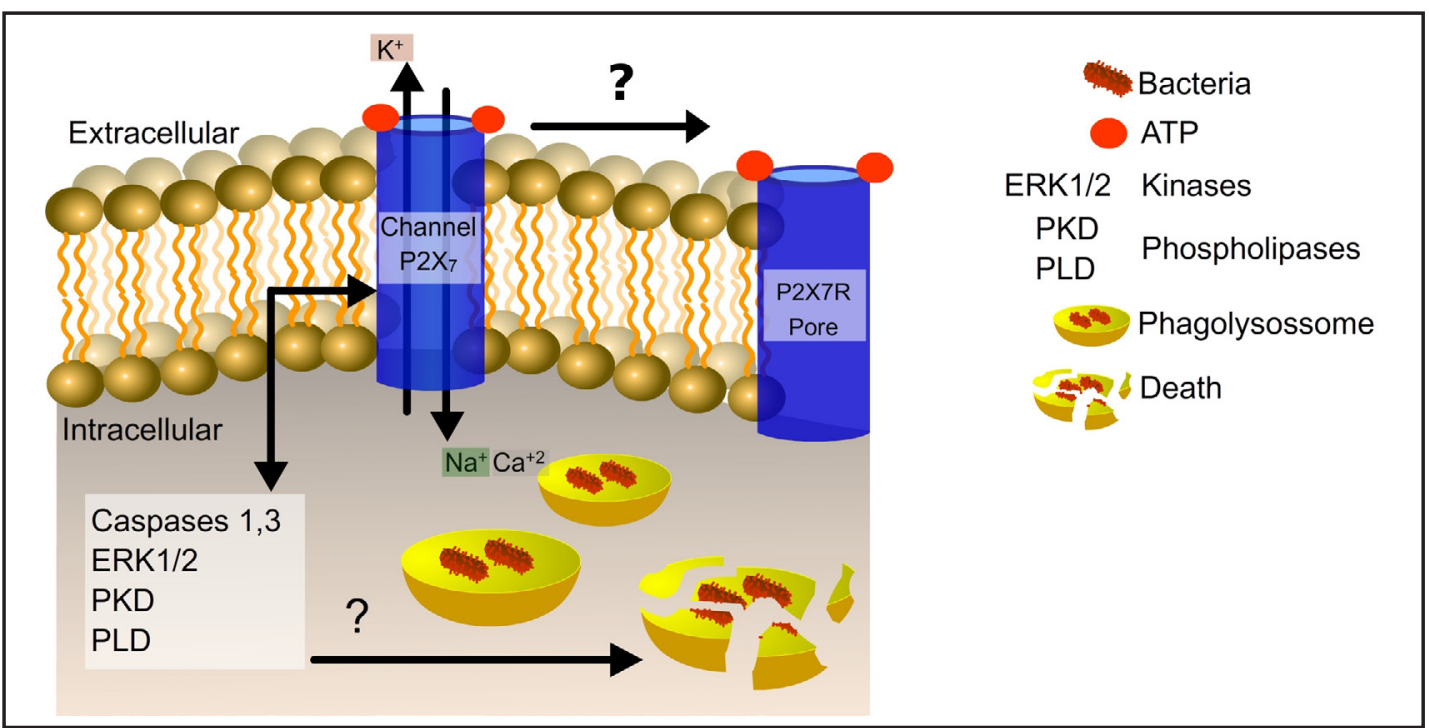

Fig. 2. The P2X7R activation stimulates signaling pathways which lead to the death of the intracellular mycobacteria.

screening of new possible selective agonist molecule for its receptor, which they could be resistant to the action of ectonucleotidases avoiding the generation of harmful byproducts, such as ADP, becomes necessary. In the future, they can be useful in the clinical treatment of MDR-TB and XDR-TB cases.

\section{ATP as a Novel Treatment for Multidrug Resistance in Tuberculosis}

As mentioned previously, the numbers of MDR-TB and XDR-TB cases have increased worldwide. MTB is an intracellular parasite, and chemotherapeutic agents must enter the cytoplasm of the infected cell to kill it. Therefore, novel medicines are essential. We speculate KARGER 


\section{Cellular Physiology Cell Physiol Biochem 2015;37:409-418 \begin{tabular}{|c|c|}
\hline DOI: 10.1159/000430364 & O 2015 S. Karger AG, Basel
\end{tabular} and Biochemistry Published online: August 28, 2015 \\ Soares-Bezerra et al.: Agonists to P2X7R for Clinical Use in Tuberculosis}

that the synergistic or additive effect of extracellular ATP (or an equivalent analog) in association with bactericidal or bacteriostatic antibiotics could be a treatment for TB. As reviewed above, extracellular ATP activates P2X7R and induces the opening of a membrane pore, which allows the passage of molecules up to $900 \mathrm{Da}$. This property could be used to increase the delivery of hydrophilic or amphipathic antibiotics to the cellular cytoplasm, such as isoniazid (MW: 137.14 Da), rifampicin (MW: 822.94 Da), ethambutol (MW: 277.2 Da) and ethionamide (MW: 166.2 Da) (Fig. 1).

In addition to the pore mechanism, P2X7R activation could kill infected macrophages and consequently MTB via apoptosis or autophagy [25, 29, 32]. P2X7R activation stimulates signaling pathways, which lead to the death of the intracellular mycobacteria (Fig. 2). Deng et al. described the influence of the MTB protein Rv1808 on the host immune cell response [60], which could be inhibited through P2X7R activation.

Amaral et al. [61] and Martins et al. [62] reported the inhibition of potassium efflux in MTB-infected macrophages as a survival pathway used by MDR-TB and XDR-TB drugresistant strains because this efflux could lead to an acidification of the phagolysosome and promote bacillus death. Therefore, the restoration of the potassium efflux could be a therapeutic target to treat infections by resistant MTB strains. In this context, P2X7R emerges as a promising target because it opens a channel that allows potassium efflux when activated by ATP. P2X7R activation by ATP causes the instantaneous opening of a cation channel, which allows for $\mathrm{Ca}^{2+}$ and $\mathrm{Na}^{+}$influx and $\mathrm{K}^{+}$efflux. This process initiates a number of downstream signaling events, such as the caspase cascade and activation of the inflammasome complex, and results in apoptosis or phospholipase D activation, which promotes the phagosomelysosome fusion and causes mycobacterial death [63-65]. A recent work published by Santos et al. established an experimental model for in vivo studies in mice to evaluate the P2X7R activity during MTB infections [66].

\section{Discussion}

Infection with multi-drug-resistant strains has become a public health problem in countries with low human development index. These infections cause millions of deaths per year, which signals the need for both improvement in the current treatment and a renewed search for new chemotherapies with greater efficacy than current medicines. This review proposed a therapeutic approach to improve current treatments, focusing on P2X7R activation using ATP, or other selective agonist molecules, as a medicine, which could act sinergically to restore the efficacy of these medicines. In the context of multi-drugresistant cases and to ameliorate the reduced potency of current medicines via low-dose administrations, which would diminish the occurrence of side effects.

\section{Disclosure Statement}

The authors declare no conflicts of interest.

\section{References}

1 Zumla A, Raviglione M, Hafner R, von Reyn CF: Tuberculosis. N Engl J Med 2013;368:745-755.

2 O‘Garra A, Redford PS, McNab FW, Bloom CI, Wilkinson RJ, Berry MP: The immune response in tuberculosis. Annu Rev Immunol 2013;31:475-527.

3 Chen K, Kolls JK: T cell-mediated host immune defenses in the lung. Annu Rev Immunol 2013;31:605-633.

4 Eurosurveillance editorial t: WHO publishes Global tuberculosis report 2013. Euro Surveill 2013;18:

5 Chiang CY, Van Weezenbeek C, Mori T, Enarson DA: Challenges to the global control of tuberculosis. Respirology 2013;18:596-604. 


\section{Cellular Physiology Cell Physiol Biochem 2015;37:409-418 \begin{tabular}{l|l|l} 
DOI: 10.1159/000430364 & (C) 2015 S. Karger AG, Basel
\end{tabular} www.karger.com/cpb \\ Soares-Bezerra et al.: Agonists to P2X7R for Clinical Use in Tuberculosis}

6 Raviglione M: XDR-TB: entering the post-antibiotic era? Int J Tuberc Lung Dis 2006;10:1185-1187.

7 Reichman LB, Schaaf HS, Pontali E, Migliori GB: A new paradigm for multidrug-resistant tuberculosis? Int J Tuberc Lung Dis 2014;18:884.

8 Ralevic V, Burnstock G: Receptors for purines and pyrimidines. Pharmacol Rev 1998;50:413-492.

9 White N, Burnstock G: P2 receptors and cancer. Trends Pharmacol Sci 2006;27:211-217.

10 Khakh BS, North RA: P2X receptors as cell-surface ATP sensors in health and disease. Nature 2006;442:527-532.

11 Kaczmarek-Hajek K, Lorinczi E, Hausmann R, Nicke A: Molecular and functional properties of P2X receptors--recent progress and persisting challenges. Purinergic Signal 2012;8:375-417.

12 Di Virgilio F: Purines, purinergic receptors, and cancer. Cancer Res 2012;72:5441-5447.

13 Khakh BS, North RA: Neuromodulation by Extracellular ATP and P2X Receptors in the CNS. Neuron 2012;76:51-69.

14 Lister MF, Sharkey J, Sawatzky DA, Hodgkiss JP, Davidson DJ, Rossi AG, Finlayson K: The role of the purinergic P2X7 receptor in inflammation. J Inflamm (Lond) 2007;4:5.

15 Ferrari D, Pizzirani C, Adinolfi E, Lemoli RM, Curti A, Idzko M, Panther E, Di VF: The P2X7 receptor: a key player in IL-1 processing and release. J Immunol 2006;176:3877-3883.

16 Loomis WH, Namiki S, Ostrom RS, Insel PA: Hypertonic stress increases T cells interleukin-2 expression through a mechanism that involves ATP release, P2 receptor, and p38 MAPK activation. J Biol Chem 2003;278:4590-4596.

17 Jacob F, Novo CP, Bachert C, Van Crombruggen K: Purinergic signaling in inflammatory cells: P2 receptor expression, functional effects, and modulation of inflammatory responses. Purinergic Signal 2013;10.1007/s11302-013-9357-4

18 Smith RA, Alvarez AJ, Estes DM: The P2X7 purinergic receptor on bovine macrophages mediates mycobacterial death. Vet Immunol Immunopathol 2001;78:249-262.

19 Mehta VB, Hart J, Wewers MD: ATP-stimulated release of interleukin (IL)-1beta and IL-18 requires priming by lipopolysaccharide and is independent of caspase-1 cleavage. J Biol Chem 2001;276:3820-3826.

20 Volonte C, Apolloni S, Skaper SD, Burnstock G: P2X7 receptors: channels, pores and more. CNS Neurol Disord Drug Targets 2012;11:705-721.

21 Sluyter R, Barden JA, Wiley JS: Detection of P2X purinergic receptors on human B lymphocytes. Cell Tissue Res 2001;304:231-236.

22 Bulanova E, Budagian V, Orinska Z, Hein M, Petersen F, Thon L, Adam D, Bulfone-Paus S: Extracellular ATP induces cytokine expression and apoptosis through P2X7 receptor in murine mast cells. J Immunol 2005;174:3880-3890.

23 Sperlagh B, Hasko G, Nemeth Z, Vizi ES: ATP released by LPS increases nitric oxide production in raw 264.7 macrophage cell line via P2Z/P2X7 receptors. Neurochem Int 1998;33:209-215.

24 Hu Y, Fisette PL, Denlinger LC, Guadarrama AG, Sommer JA, Proctor RA, Bertics PJ: Purinergic receptor modulation of lipopolysaccharide signaling and inducible nitric-oxide synthase expression in RAW 264.7 macrophages. J Biol Chem 1998;273:27170-27175.

25 Saunders BM, Fernando SL, Sluyter R, Britton WJ, Wiley JS: A loss-of-function polymorphism in the human P2X7 receptor abolishes ATP-mediated killing of mycobacteria. J Immunol 2003;171:5442-5446.

26 Sikora A, Liu J, Brosnan C, Buell G, Chessel I, Bloom BR: Cutting edge: purinergic signaling regulates radical-mediated bacterial killing mechanisms in macrophages through a P2X7-independent mechanism. J Immunol 1999;163:558-561.

27 Friedle SA, Curet MA, Watters JJ: Recent patents on novel P2X(7) receptor antagonists and their potential for reducing central nervous system inflammation. Recent Pat CNS Drug Discov 2010;5:35-45.

28 Fernando SL, Saunders BM, Sluyter R, Skarratt KK, Wiley JS, Britton WJ: Gene dosage determines the negative effects of polymorphic alleles of the P2X7 receptor on adenosine triphosphate-mediated killing of mycobacteria by human macrophages. J Infect Dis 2005;192:149-155.

29 Fernando SL, Saunders BM, Sluyter R, Skarratt KK, Goldberg H, Marks GB, Wiley JS, Britton WJ: A polymorphism in the P2X7 gene increases susceptibility to extrapulmonary tuberculosis. Am J Respir Crit Care Med 2007;175:360-366.

30 Bahari G, Hashemi M, Taheri M, Naderi M, Moazeni-Roodi A, Kouhpayeh HR, Eskandari-Nasab E: Association of P2X7 gene polymorphisms with susceptibility to pulmonary tuberculosis in Zahedan, Southeast Iran. Genet Mol Res 2013;12:160-166. 


\section{Cellular Physiology Cell Physiol Biochem 2015;37:409-418 \begin{tabular}{l|l|l} 
DOI: 10.1159/000430364 & (C) 2015 S. Karger AG, Basel
\end{tabular} and Biochemistry Published online: August 28, 2015

31 Placido R, Auricchio G, Falzoni S, Battistini L, Colizzi V, Brunetti E, Di Virgilio F, Mancino G: P2X(7) purinergic receptors and extracellular ATP mediate apoptosis of human monocytes/macrophages infected with Mycobacterium tuberculosis reducing the intracellular bacterial viability. Cell Immunol 2006;244:1018.

32 Ramachandra L, Qu Y, Wang Y, Lewis CJ, Cobb BA, Takatsu K, Boom WH, Dubyak GR, Harding CV: Mycobacterium tuberculosis synergizes with ATP to induce release of microvesicles and exosomes containing major histocompatibility complex class II molecules capable of antigen presentation. Infect Immun 2010;78:5116-5125.

33 Amaral EP, Ribeiro SC, Lanes VR, Almeida FM, de Andrade MR, Bomfim CC, Salles EM, Bortoluci KR, Coutinho-Silva R, Hirata MH, Alvarez JM, Lasunskaia EB, D`Imperio-Lima MR: Pulmonary infection with hypervirulent Mycobacteria reveals a crucial role for the P2X7 receptor in aggressive forms of tuberculosis. PLoS Pathog 2014;10:e1004188.

34 Areeshi MY, Mandal RK, Panda AK, Haque S: Association of P2X7 A1513C (rs3751143) gene polymorphism with risk of tuberculosis: evidence from a meta-analysis. Genet Test Mol Biomarkers 2013;17:662-668.

35 Wu G, Zhao M, Gu X, Yao Y, Liu H, Song Y: The effect of P2X7 receptor 1513 polymorphism on susceptibility to tuberculosis: A meta-analysis. Infect Genet Evol 2014;24:82-91.

36 Li W, He J, Xie L, Chen T, Xie J: Comparative genomic insights into the biosynthesis and regulation of mycobacterial siderophores. Cell Physiol Biochem 2013;31:1-13.

37 Abate D, Tedla Y, Meressa D, Ameni G: Isoniazid and rifampicin resistance mutations and their effect on second-line anti-tuberculosis treatment. Int J Tuberc Lung Dis 2014;18:946-951.

38 Carlstrom B, Lovgren O: Treatment of Rheumatoid Arthritis with ATP. Ann Rheum Dis 1949;8:293-295.

39 Haskell CM, Wong M, Williams A, Lee LY: Phase I trial of extracellular adenosine 5'-triphosphate in patients with advanced cancer. Med Pediatr Oncol 1996;27:165-173.

40 Agteresch HJ, Dagnelie PC, Rietveld T, van den Berg JW, Danser AH, Wilson JH: Pharmacokinetics of intravenous ATP in cancer patients. Eur J Clin Pharmacol 2000;56:49-55.

41 Agteresch HJ, Dagnelie PC, van der GA, Stijnen T, Wilson JH: Randomized clinical trial of adenosine 5'-triphosphate in patients with advanced non-small-cell lung cancer. J Natl Cancer Inst. 2000;92:321-328.

42 Agteresch HJ, Leij-Halfwerk S, Van Den Berg JW, Hordijk-Luijk CH, Wilson JH, Dagnelie PC: Effects of ATP infusion on glucose turnover and gluconeogenesis in patients with advanced non-small-cell lung cancer. Clin Sci (Lond) 2000;98:689-695.

43 Agteresch HJ, Rietveld T, Kerkhofs LG, van den Berg JW, Wilson JH, Dagnelie PC: Beneficial effects of adenosine triphosphate on nutritional status in advanced lung cancer patients: a randomized clinical trial. J Clin Oncol 2002;20:371-378.

44 Beijer S, Gielisse EA, Hupperets PS, van den Borne BE, van den Beuken-van Everdingen M, Nijziel MR, van Henten AM, Dagnelie PC: Intravenous ATP infusions can be safely administered in the home setting: a study in pre-terminal cancer patients. Invest New Drugs 2007;25:571-579.

45 Agteresch HJ, Dagnelie PC, van der Gaast A, Stijnen T, Wilson JH: Randomized clinical trial of adenosine 5'-triphosphate in patients with advanced non-small-cell lung cancer. J Natl Cancer Inst 2000;92:321-328.

46 Pellegatti P, Raffaghello L, Bianchi G, Piccardi F, Pistoia V, Di Virgilio F: Increased level of extracellular ATP at tumor sites: in vivo imaging with plasma membrane luciferase. PLoS One 2008;3:e2599.

47 Wilhelm K, Ganesan J, Muller T, Durr C, Grimm M, Beilhack A, Krempl CD, Sorichter S, Gerlach UV, Juttner E, Zerweck A, Gartner F, Pellegatti P, Di Virgilio F, Ferrari D, Kambham N, Fisch P, Finke J, Idzko M, Zeiser R: Graft-versus-host disease is enhanced by extracellular ATP activating P2X7R. Nat Med 2010;16:1434-1438.

48 Mortensen SP, Thaning P, Nyberg M, Saltin B, Hellsten Y: Local release of ATP into the arterial inflow and venous drainage of human skeletal muscle: insight from ATP determination with the intravascular microdialysis technique. J Physiol 2011;589:1847-1857.

49 Arts IC, Coolen EJ, Bours MJ, Huyghebaert N, Stuart MA, Bast A, Dagnelie PC: Adenosine 5'-triphosphate (ATP) supplements are not orally bioavailable: a randomized, placebo-controlled cross-over trial in healthy humans. J Int Soc Sports Nutr 2012;9:16.

50 Long G, Zhang GQ: Effects of Adenosine Triphosphate (ATP) on Early Recovery After Total Knee Arthroplasty (TKA): A Randomized, Double-Blind, Controlled Study. J Arthroplasty 2014;10.1016/j. arth.2014.03.025

51 Jamnik S, Santoro IL, Uehara C: Comparative study of prognostic factors among longer and shorter survival patients with bronchogenic carcinoma. J Pneumol 2002;28:245-249. 


\section{Cellular Physiology Cell Physiol Biochem 2015;37:409-418 \begin{tabular}{l|l|l} 
DOI: 10.1159/000430364 & (C) 2015 S. Karger AG, Basel
\end{tabular} and Biochemistry Published online: August 28, 2015

52 Nogueira JA, Marques RRC, Silva TR, França UM, Villa TCS, Palha PF: Caracterização clínico-epidemiológica dos pacientes com diagnóstico de tuberculose resistente às drogas em João Pessoa, PB. Rev Eletr Enf 2008;4:979-989.

53 Guo Y, Mishra A, Weng T, Chintagari NR, Wang Y, Zhao C, Huang C, Liu L: Wnt3a mitigates acute lung injury by reducing P2X7 receptor-mediated alveolar epithelial type I cell death. Cell Death Dis 2014;5:e1286.

54 Woods LT, Camden JM, Batek JM, Petris MJ, Erb L, Weisman GA: P2X7 receptor activation induces inflammatory responses in salivary gland epithelium. Am J Physiol Cell Physiol 2012;303:C790-801.

55 Zhou JZ, Riquelme MA, Gao X, Ellies LG, Sun LZ, Jiang JX: Differential impact of adenosine nucleotides released by osteocytes on breast cancer growth and bone metastasis. Oncogene 2014;10.1038/ onc.2014.113

56 Chen S, Ma Q, Krafft PR, Hu Q, Rolland W, 2nd, Sherchan P, Zhang J, Tang J, Zhang JH: P2X7R/cryopyrin inflammasome axis inhibition reduces neuroinflammation after SAH. Neurobiol Dis 2013;58:296-307.

57 Bhattacharya A, Wang Q, Ao H, Shoblock JR, Lord B, Aluisio L, Fraser I, Nepomuceno D, Neff RA, Welty N, Lovenberg TW, Bonaventure P, Wickenden AD, Letavic MA: Pharmacological characterization of a novel centrally permeable P2X7 receptor antagonist: JNJ-47965567. Br J Pharmacol 2013;170:624-640.

58 Xu XJ, Boumechache M, Robinson LE, Marschall V, Gorecki DC, Masin M, Murrell-Lagnado RD: Splice variants of the P2X7 receptor reveal differential agonist dependence and functional coupling with pannexin-1. J Cell Sci 2012;125:3776-3789.

59 Norenberg W, Hempel C, Urban N, Sobottka H, Illes P, Schaefer M: Clemastine potentiates the human P2X7 receptor by sensitizing it to lower ATP concentrations. J Biol Chem 2011;286:11067-11081.

60 Deng W, Li W, Zeng J, Zhao Q, Li C, Zhao Y, Xie J: Mycobacterium tuberculosis PPE family protein Rv1808 manipulates cytokines profile via co-activation of MAPK and NF-kappaB signaling pathways. Cell Physiol Biochem 2014;33:273-288.

61 Amaral L, Martins M, Viveiros M: Enhanced killing of intracellular multidrug-resistant Mycobacterium Tuberculosis by compounds that affect the activity of efflux pumps. J Antimicrob Chemother 2007;59:1237-1246.

62 Martins M, Viveiros M, Couto I, Amaral L: Targeting human macrophages for enhanced killing of intracellular XDR-TB and MDR-TB. Int J Tuberc Lung Dis 2009;13:569-573.

63 Humphreys BD, Rice J, Kertesy SB, Dubyak GR: Stress-activated protein kinase/JNK activation and apoptotic induction by the macrophage P2X7 nucleotide receptor. J Biol Chem 2000;275:26792-26798.

64 Kusner DJ, Barton JA: ATP stimulates human macrophages to kill intracellular virulent Mycobacterium tuberculosis via calcium-dependent phagosome-lysosome fusion. J Immunol 2001;167:3308-3315.

65 Coutinho-Silva R, Stahl L, Raymond MN, Jungas T, Verbeke P, Burnstock G, Darville T, Ojcius DM: Inhibition of chlamydial infectious activity due to P2X7R-dependent phospholipase D activation. Immunity 2003;19:403-412.

66 Santos AA, Jr., Rodrigues-Junior V, Zanin RF, Borges TJ, Bonorino C, Coutinho-Silva R, Takyia CM, Santos DS, Campos MM, Morrone FB: Implication of purinergic P2X7 receptor in M. tuberculosis infection and host interaction mechanisms: A mouse model study. Immunobiology 2013;10.1016/j.imbio.2013.03.003

67 Lammas DA, Stober C, Harvey CJ, Kendrick N, Panchalingam S, Kumararatne DS: ATP-induced killing of mycobacteria by human macrophages is mediated by purinergic P2Z(P2X7) receptors. Immunity 1997; 7:433-444.

68 Humphreys BD, Rice J, Kertesy SB, Dubyak GR: Stress-activated protein kinase/JNK activation and apoptotic induction by the macrophage P2X7 nucleotide receptor. J Biol Chem 2000;275:26792-26798.

69 Songane M, Kleinnijenhuis J, Netea MG, van Crevel R: The role of autophagy in host defence against Mycobacterium tuberculosis infection. Tuberculosis (Edinb) 2012;92:388-396.

70 Wilson JM, Joy JM, Lowery RP, Roberts MD, Lockwood CM, Manninen AH, Fuller JC, De Souza EO, Baier SM, Wilson SM, Rathmacher JA: Effects of oral adenosine-5'-triphosphate supplementation on athletic performance, skeletal muscle hypertrophy and recovery in resistance-trained men. Nutr Metab (Lond) 2013;10:57.

71 Beijer S, Gielisse EaR, Hupperets PS, van den Borne BEEM, van den Beuken-van Everdingen M, Nijziel MR, van Henten AMJ, Dagnelie PC: Intravenous ATP infusions can be safely administered in the home setting: a study in pre-terminal cancer patients. Invest New Drugs 2007;25:571-579. 